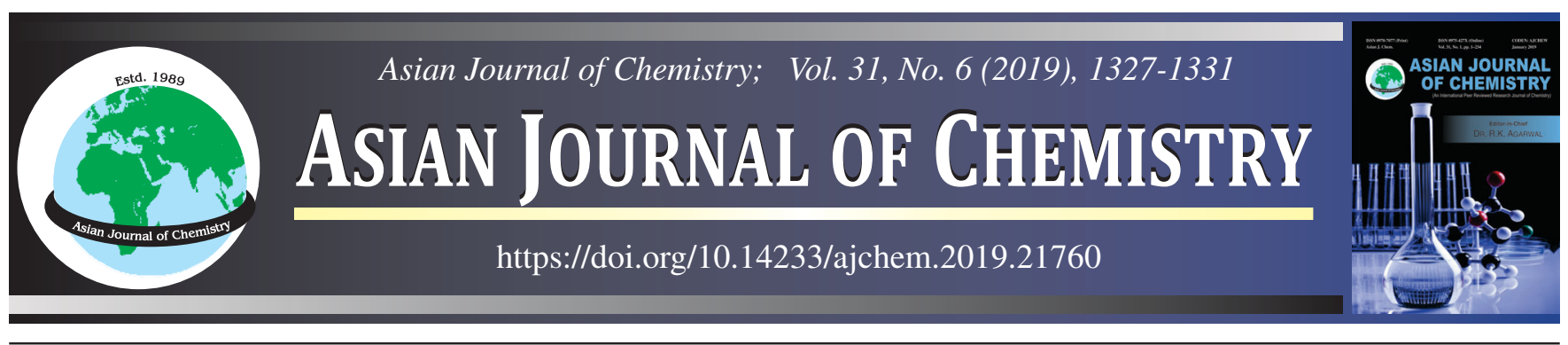

\title{
Effective Removal of Hexavalent Chromium from Polluted Water using Phoenix sylvestris Seed Powder as Adsorbent
}

\author{
P. Karunasri Meghana, K. Venkata Pravalika, P. Janaki Sriram and K. Ravindhranath*,
}

Department of Chemistry, K L University, Green Fields, Vaddeswaram-522502, India

*Corresponding author: E-mail: ravindhranath.kunta@gmail.com

Received: 13 October 2018; Accepted: 27 February 2019; Published online: 29 April 2019;

Phoenix sylvestris seed powder (PSSP) was investigated as an adsorbent for the removal of chromium(VI) ions from water using batch extraction method. The conditions for the maximum extraction were optimized. The adsorption capacity was found to be $22.5 \mathrm{mg} / \mathrm{g}$ at $\mathrm{pH}$ $=2$, contact time: $60 \mathrm{~min}$, PSSP dosage: $0.40 \mathrm{~g} / 500 \mathrm{~mL}$, rpm: 300 and temp.: $28 \pm 2{ }^{\circ} \mathrm{C}$ and found to be more suitable adsorbant than compared to other reported adsorbents in the literature. Co-ions even in five-fold excess were less interfered. Regeneration studies revealed that Phoenix sylvestris seed powder can be used up to three cycles. The method developed was successfully applied to polluted water/ industrial effluents samples.

Keywords: Phoenix sylvestris seed powder, Hexavalent Chromium, Adsorption.

\section{INTRODUCTION}

The removal of chromium ions from water is one of the important aspects of pollution control research as the species are highly toxic [1-6]. The contamination of water with the chromium species mainly arises due to the ill-treated or untreated disposal of effluents from chromium based industries [1-8].

Besides the various conventional methods [7-10], growing interest is seen in adopting unconventional adsorbents for the extraction of chromium species from water in view of economy and effectiveness. Various biomaterials such as active carbons [11-13], fly ash [14], bone charcoal [15], microbes [16], modified zeolites [17,18], coconut fiber [19], bioaccumulation [20], maple sawdust [21], eucalyptus bark [22], waste tea leaves and rice husk [23], Hevea brasilinesis sawdust [24] and neem sawdust [25] are investigated for the removal of chromium ions from water. Spent coffee grounds [26], Nerium odorum and Calotropis zygantia [27], Chenopodium album and Eclipta prostrate [28], Anogeissus latifolia and Hardwickia binata [29], Justicia adhatoda, Cissus quadrangularis and Soapnut acacia [30], Salvadora persico and Caesalpinia bonduc plants [31]. Croton tiglium and Cassia occidentalis [32], and Azadirachta indica, Syzygium cumini and Acacia arabica [33] were also investigated as adsorbents.
Our research group is working on these same outlines and found some successful methods for the removal of various toxic ions using biomaterials as adsorbents [34-40]. While searching various plant materials for their possible use as adsorbents in the removal of various toxic ions, it is noticed that there is a strong affinity between the seeds powders of Phoenix sylvestris plant and chromium(VI) ions. Hence, Phoenix sylvestris seed powder (PSSP) is investigated as adsorbent in the present work for the removal of chromium(VI) from wastewaters by optimizing the various physico-chemical parameters. The procedure developed is applied to real polluted waters/industrial effluents.

\section{EXPERIMENTAL}

All the chemical used were of analytical grade. Double distilled water was used for the preparation of solutions. Stock solution $(500 \mathrm{mg} / \mathrm{L})$ was prepared and suitably diluted as per the need. Diphenyl carbazide $(0.25 \%)$ in $50 \%$ of acetone and $6 \mathrm{~N} \mathrm{H}_{2} \mathrm{SO}_{4}$ was used as colour developing agent.

Adsorbent: Phoenix Sylvestris tree (wild palm tree) is common in India and grows even in shades (absence of proper sunlight) to a height of 1 to 12 meters. It belongs to Arecaceae family in plant kingdom. The fruits of the tree form on about

This is an open access journal, and articles are distributed under the terms of the Creative Commons Attribution-NonCommercial-ShareAlike 4.0 (CC BY-NC-SA 4.0) International License which allows readers to freely read, download, copy, distribute, print, search, or link to the full texts of its articles and to use them for any other lawful non-commercial purpose as long as the original source is duly acknowledged. 
1 meter long pendulous stem having a number of bunches. The fruits were collected, washed, sun-dried and their skins were peeled off. The seed obtained were oven dried at $105^{\circ} \mathrm{C}$ for about $2 \mathrm{~h}$ and then crushed to powder of less than $75 \mu$ in size.

Method: Procedures based on batch methods were adopted [7-9]. Known quantities of Phoenix sylvestris seed powder were taken into $1 \mathrm{~L} / 500 \mathrm{~mL}$ stopper bottles containing $500 \mathrm{~mL} / 250 \mathrm{~mL}$ of potassium dichromate solution of known concentrations. Initial $\mathrm{pHs}$ of the solutions were adjusted with dil. $\mathrm{HCl} /$ dil. $\mathrm{NaOH}$ using $\mathrm{pH}$ meter. The samples were agitated in mechanical shakers for a desired time and filtered. The residual amounts of $\mathrm{Cr}(\mathrm{VI})$ were determined adopting diphenyl carbazide method [41].

The effect of various parameters such as equilibration time, initial $\mathrm{pH}$, sorbent dosage, etc. on the extraction of $\mathrm{Cr}(\mathrm{VI})$ onto the surface of Phoenix sylvestris seed powder were investigated. Interference caused by five-fold excess of co-ions (naturally existing) on the removal of chromium(VI) was also investigated. The methodology developed was applied to real polluted water samples namely, effluents of tannery and chrome plating industries.

\section{RESULTS AND DISCUSSION}

Initial pH of equilibrium system: $\mathrm{pH}$ of agitating solution is found to effect the removal percentage profoundly. With the increase in $\mathrm{pH}$, the extraction percentage is decreased (Fig. 1). The removal $\%$ is found to be $90 \%$ at $\mathrm{pH}: 2 ; 85 \%$ at $\mathrm{pH} 4$; 63 at $\mathrm{pH}: 6 ; 50 \%$ at $\mathrm{pH}: 8 ; 20 \%$ at $\mathrm{pH}: 10$ and $5 \%$ at $\mathrm{pH}: 12$, at other optimum extraction conditions namely, Phoenix sylvestris seed powder (PSSP) dosage: $0.8 \mathrm{~g} / \mathrm{L}, \mathrm{rpm}: 300$, equilibration period: $60 \mathrm{~min}$ and temp.: $28 \pm 1{ }^{\circ} \mathrm{C}$.

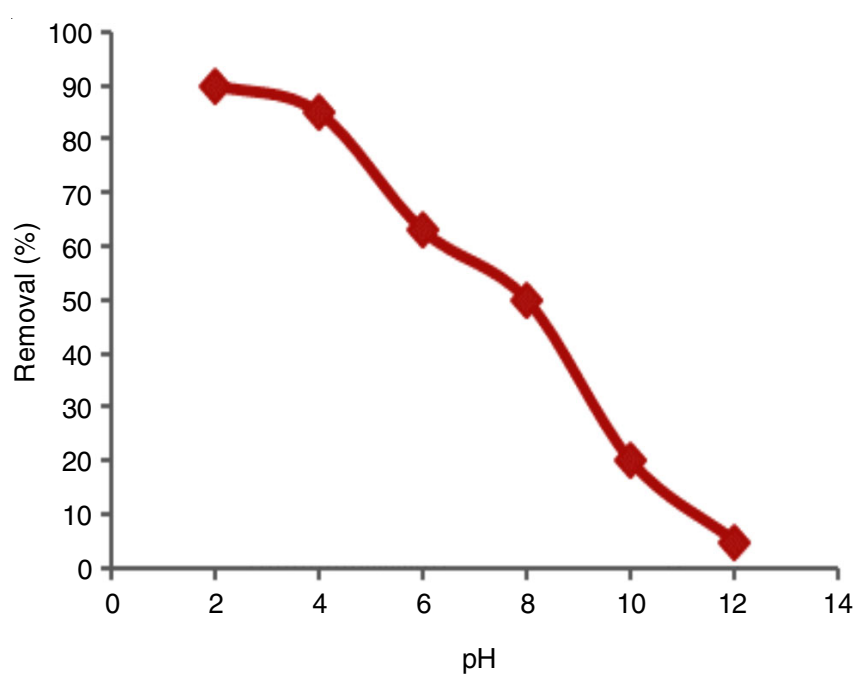

Fig. 1. Effect of $\mathrm{pH}$ on the adsorption of the $\mathrm{Cr}(\mathrm{VI})$

The adsorption behaviour may be understood from the view point of $\mathrm{pH}$ of zero point of charge (pHzpc). The $\mathrm{pHzpc}$ for Phoenix sylvestris seed powder (PSSP) is found to be 3.5 (Fig. 2). So above this $\mathrm{pH}$, the surface of adsorbent possesses negative charge due to the dissociation of functional groups $(-\mathrm{OH},-\mathrm{COOH}$, etc. $)$ present on the surface of adsorbent and below this pHzpc, the dissociation is less favoured and moreover protination also may occur at sufficiently low $\mathrm{pHs}$. Thus

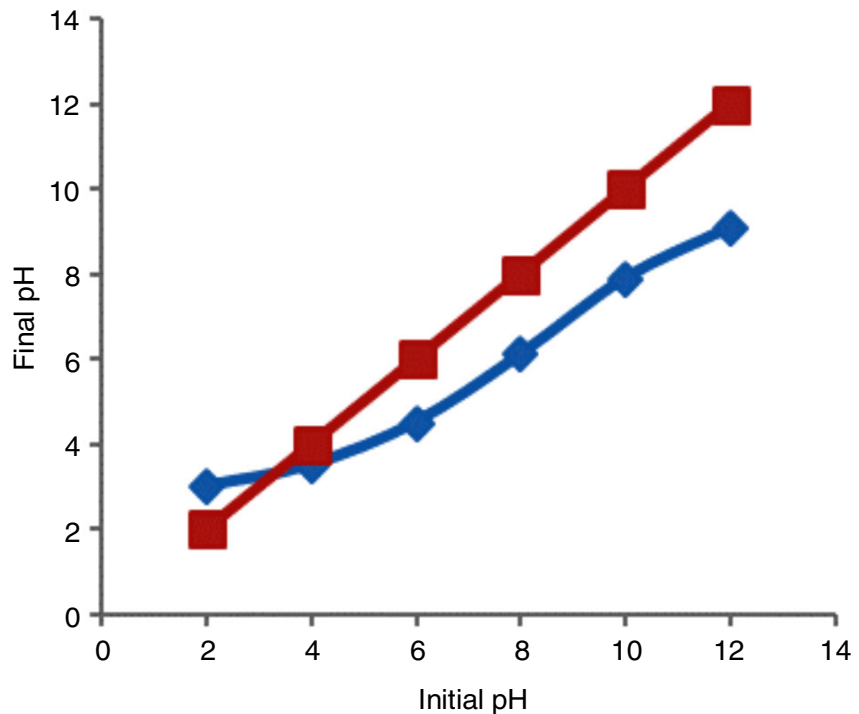

Fig. 2. $\mathrm{pH}_{\mathrm{ZPC}}$ of PSSP

the surface of adsorbent shows different thrusts towards cations or anions depending upon the $\mathrm{pH}$ conditions of the equilibrium mixture. At low $\mathrm{pH}$ solutions $(\approx 2)$, adsorption of chromate, an anion is favoured because the surface of adsorbent is positively charged while at higher pHs, the adsorption is less favoured as the inter-surface is negatively charged. Hence, the removal percentage is more with decrease in $\mathrm{pH}$ of the extraction mixture.

Agitation time: As the time of equilibration between the adsorbent, Phoenix sylvestris seed powder (PSSP) and the adsorbate (chromate) solution is varied, the extraction percentage is also changed (Fig. 3). The removal $\%$ is found to be $40 \%$ at $15 \mathrm{~min}$, $65 \%$ at $30 \mathrm{~min}, 75 \%$ at $45 \mathrm{~min}, 90 \%$ at $60 \mathrm{~min}$ and above. A steady state is reached after $60 \mathrm{~min}$ of equilibration time.

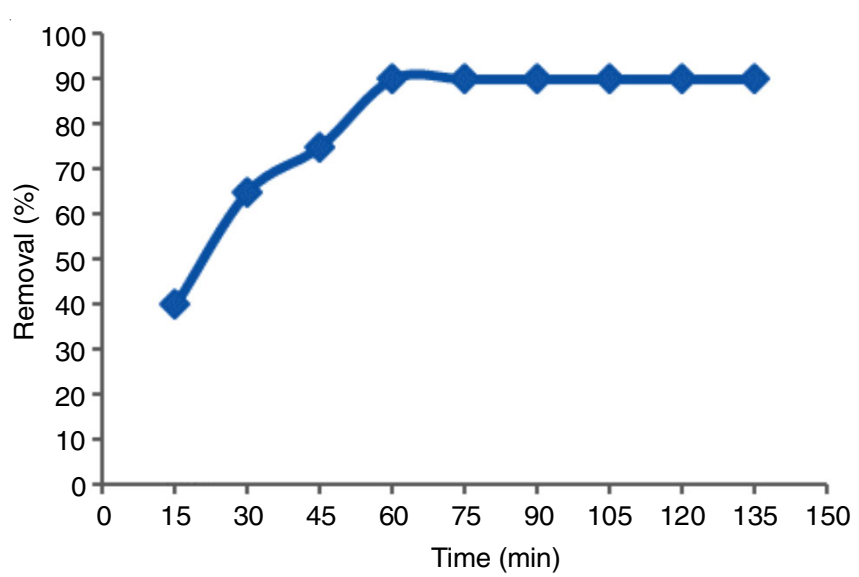

Fig. 3. Contact time vs. \% removal of $\mathrm{Cr}(\mathrm{VI})$

Phoenix sylvestris seed powder (PSSP) dosage: The effect of PSSP concentration on the removal percentage of chromium (VI) is shown in Fig. 4. The concentration is varied from 100 $\mathrm{mg} / 500 \mathrm{~mL}$ to $800 \mathrm{mg} / 500 \mathrm{~mL}$. With the increase in the PSSP concentration, the removal precentage is progressively increased and the maximum of $90 \%$ extraction of chromium(VI) is observed at and above $400 \mathrm{mg} / 500 \mathrm{~mL}$ adsorbent concentration. The adsorption capacity is $22.5 \mathrm{mg} / \mathrm{g}$ and found to be excellent adsorbant as compared to several adsorbents reported in the literature [42-48] . 


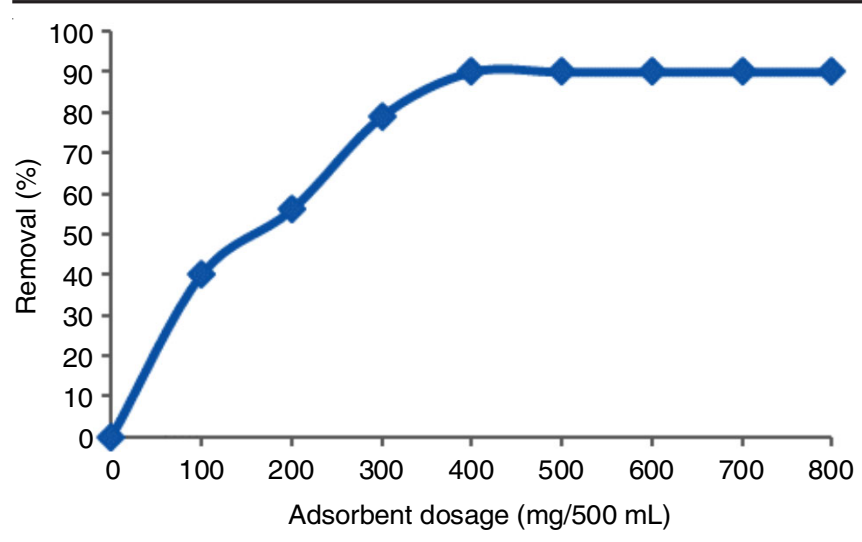

Fig. 4. Adsorbent dosage vs. \% removal of $\mathrm{Cr}(\mathrm{VI})$

Initial concentration: The effect of initial concentration of chromium(VI) on the percentage removal of $\mathrm{Cr}^{6+}$ is investigated by varying the initial concentration from $20 \mathrm{mg} / \mathrm{L}$ to 100 $\mathrm{mg} / \mathrm{L}$ while keeping the other extraction conditions at optimum levels viz., pH: 2 agitation time: $60 \mathrm{~min}$, PSSP dosage: $0.4 \mathrm{~g} / 500$ $\mathrm{mL}$; rpm: 300 and temp.: $28 \pm 2{ }^{\circ} \mathrm{C}$. As the initial concentration increases, the removal percentage is also decreased (Fig. 5) means $90 \%$ at $20 \mathrm{mg} / \mathrm{L} ; 82 \%$ at $30 \mathrm{mg} / \mathrm{L} ; 80 \%$ at $40 \mathrm{mg} / \mathrm{L} ; 72 \%$ at $50 \mathrm{mg} / \mathrm{L} ; 65 \%$ at $60 \mathrm{mg} / \mathrm{L} ; 60 \%$ at $70 \mathrm{mg} / \mathrm{L} ; 53 \%$ at $80 \mathrm{mg} / \mathrm{L}$; $50 \%$ at $90 \mathrm{mg} / \mathrm{L} ; 45 \%$ at $100 \mathrm{mg} / \mathrm{L}$. At low concentration of chromium(VI), the availability of active sites on the adsorbent (PSSP) is more and hence greater removal. As the concentration of chromium(VI) is progressively increased, the demand for active sites increased but for the fixed adsorbent concentration $(0.4 \mathrm{~g} / 500 \mathrm{~mL})$, the availability is less and hence, the removal percentage is decreased with the increase in the initial concentration of adsorbate (chromate).

Interference of co-ions: The removal percentage of chromate is investigated in the presence of five-fold excess of co-cations and anions while keeping other extraction conditions at optimum levels. The results obtained are shown in Fig. 6. It is interesting to note that substantial amounts of chromium(VI) are removed and the interference of co-ions is less. Co-anions are interfered

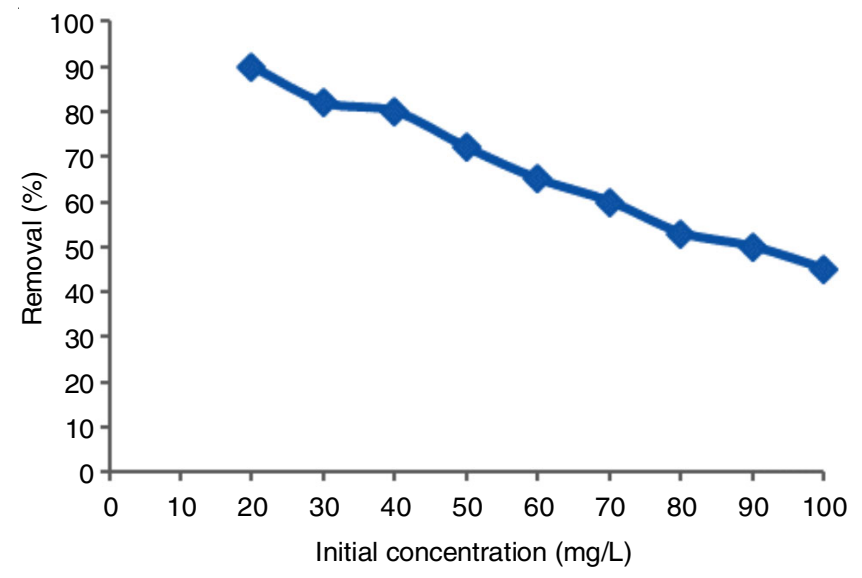

Fig. 5. Initial concentration of $\mathrm{Cr}(\mathrm{VI})$ vs. \% removal of $\mathrm{Cr}(\mathrm{VI})$

in the order: $\mathrm{PO}_{4}{ }^{3-}>\mathrm{SO}_{4}{ }^{2-}>\mathrm{Cl}^{-}>\mathrm{HCO}_{3}{ }^{-}>\mathrm{NO}_{3}{ }^{-}$while cocations in the order: $\mathrm{Zn}^{2+}>\mathrm{Cu}^{2+}>\mathrm{Ca}^{2+}>\mathrm{Mg}^{2+}>>\mathrm{Fe}^{2+}$. In any case, the percentage removal has not come down below $75 \%$ indicating that effectiveness of the adsorbent towards highly toxic chromium(VI) ions.

Applications: The adoptability of present adsorbent (PSSP) for removing chromium (VI) from polluted waters viz., effluents from tannery, chrome plating industries and lake water were investigated and the results are presented in Table-1. As is evident from the data that substantial amounts of chromate is removed and hence, the adsorbent can be used in the treatment of wastewater/industrial effluents.

Regeneration and reuse: If the spent adsorbent is regenerated and reused, the cost of procedure is effectively decreased. So, the regeneration of spent PSSP is investigated using various eluting agents. It is found that $0.1 \mathrm{M} \mathrm{NaOH}$ is successful but with decrease in efficiency (Fig. 7). With 1st, 2nd, 3rd, 4th and 5 th regenerations, the removal percentage of chromate is found to be $90,86,82,75$ and $50 \%$, respectively. Hence, the spent adsorbent can be regenerated until three cycles.

Comparative study with the reported adsorbents: The adsorption capacity of the present developed adsorbent PSSP
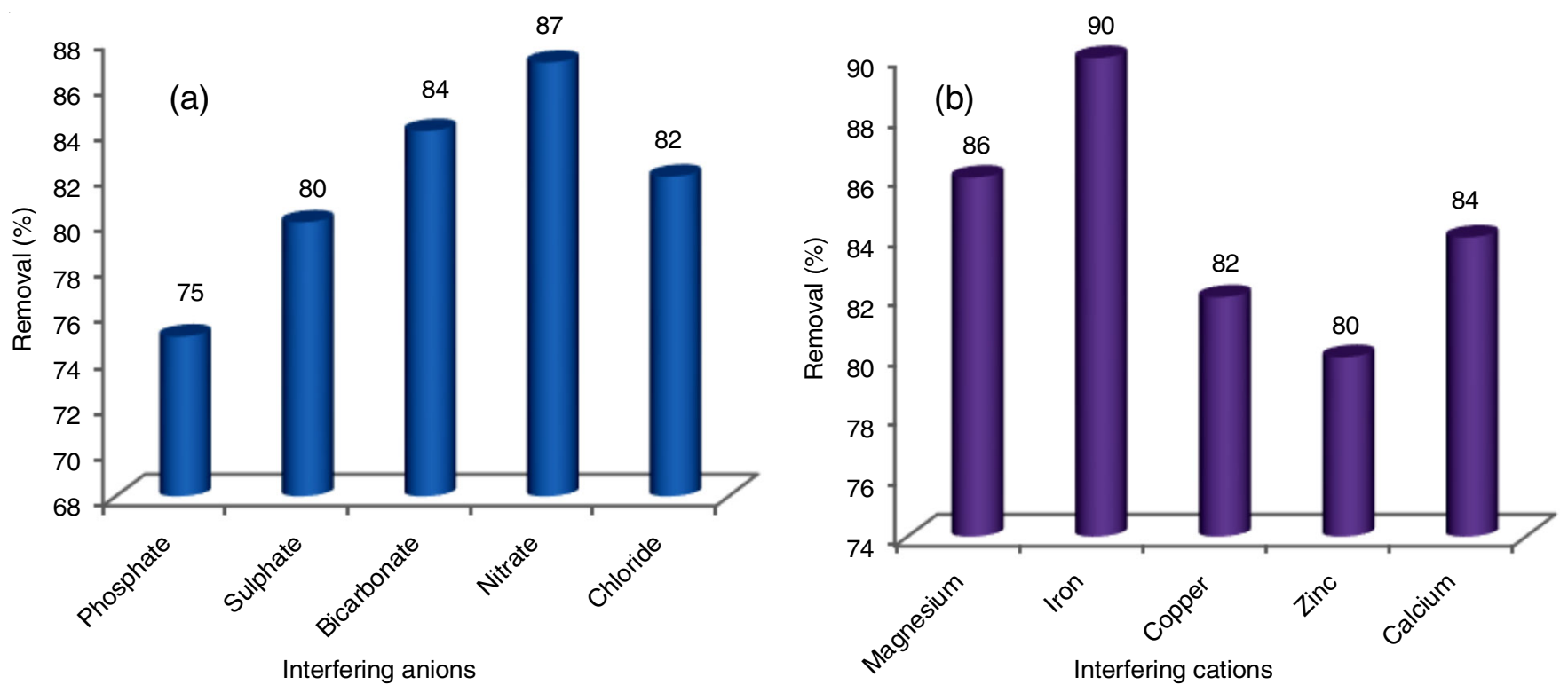

Fig. 6. (a) Interference of co-anions on \% removal of chromate; (b) Interference of co-catons on \% removal of chromate 


\begin{tabular}{|c|c|c|c|c|c|}
\hline \multicolumn{6}{|c|}{$\begin{array}{l}\text { TABLE-2 } \\
\text { COMPARISON OF CHROMIUM(VI) ADSORPTION CAPACITIES OF VARIOUS ADSORBENTS } \\
\text { REPORTED IN LITERATURE WITH Phoenix sylvestris SEED POWDER (PSSP) }\end{array}$} \\
\hline S. No. & Adsorbent & $\mathrm{pH}$ & $\begin{array}{l}\text { Initial conc. } \\
\mathrm{Cr}(\mathrm{VI})(\mathrm{mg} / \mathrm{L})\end{array}$ & $\begin{array}{l}\text { Adsorption capacity } \\
\text { towards } \mathrm{Cr}(\mathrm{VI})(\mathrm{mg} / \mathrm{g})\end{array}$ & Ref. \\
\hline 1 & Coconut tree sawdust & 3 & 20 & 3.6 & {$[42]$} \\
\hline 3 & Coconut shell carbon & 4 & 25 & 20 & [43] \\
\hline 2 & Beech sawdust & 1 & 200 & 16.10 & [48] \\
\hline 5 & Hazelnut shell & - & - & 17.70 & {$[47]$} \\
\hline 7 & Red mud modified by lanthanum & 2 & 50 & 17.35 & [44] \\
\hline 4 & Sugarcane bagasse & 2 & 500 & 13.40 & [45] \\
\hline 6 & Treated sawdust of Indian rosewood & 3 & 10 & 10.0 & [46] \\
\hline 8 & Phoenix sylvestris seeds powder (PSSP) & 2 & 20 & $22.5 \mathrm{mg} / \mathrm{g}$ & Present work \\
\hline
\end{tabular}

\begin{tabular}{cccc}
\multicolumn{5}{c}{ TABLE-1 } \\
\multicolumn{5}{c}{$\begin{array}{c}\text { REMOVAL OF CHROMIUM(VI) FROM SAMPLES } \\
\text { COLLECTED FROM VARIOUS SOURCES }\end{array}$} \\
\hline \multirow{2}{*}{ Samples } & $\begin{array}{c}\text { Initial Cr(VI) } \\
\text { conc. (mg/L) }\end{array}$ & $\begin{array}{c}\text { Cr(VI) conc. after } \\
\text { extraction (mg/L) }\end{array}$ & Removal (\%) \\
\hline \multicolumn{4}{c}{ Tannery industries } \\
\hline 1 & 10.0 & 1.2 & 88.0 \\
2 & 8.3 & 1.0 & 88.0 \\
3 & 9.0 & 1.3 & 85.5 \\
\hline \multicolumn{5}{c}{ Chromate plating industries } \\
\hline 1 & 12.5 & 1.5 & 88.0 \\
3 & 14.5 & 2.0 & 86.2 \\
\hline Natural lake samples (fed with known amounts of chromates) & 2.5 \\
\hline 1 & 16.0 & 1.8 & 88.0 \\
2 & 15.0 & 2.9 & 85.5 \\
3 & 20.0 & 2.8 & 88.8 \\
\hline
\end{tabular}

(pH: 2, PSSP dosage: $0.4 \mathrm{~g} / 500 \mathrm{~mL}$, time of equilibration: $60 \mathrm{~min}$, rpm: 300 and temperature $28 \pm 2{ }^{\circ} \mathrm{C}$ ).

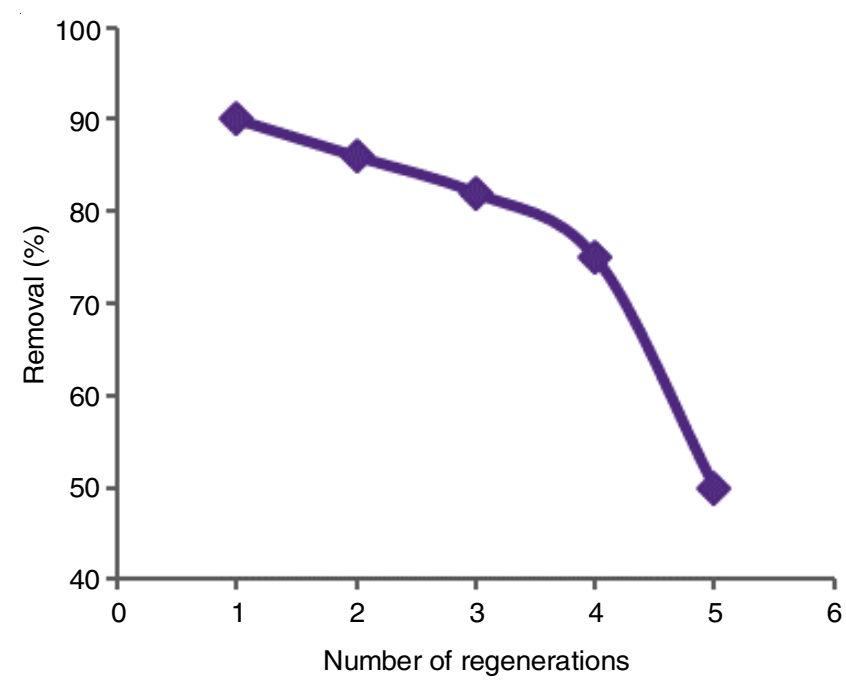

Fig. 7. Number of regenarations vs. \% removal

is compared with the reported adsorbents in the literature (Table-2). It can be inferred that PSSP has more adsorption capacity towards chromate than other reported adsorbents.

\section{Conclusion}

An adsorbent derived from Phoenix sylvestris seeds powder (PSSP) is investigated for its adsorption nature towards chromate ions from water using simulated waters. By varying various physico-chemical parameters such as $\mathrm{pH}$, sorbent dosage, time of equilibration, initial concentration of chromium
(VI), etc., the optimum conditions for the maximum extraction of chromate ions are optimized. Extraction of chromium(VI) is $90 \%$ at $\mathrm{pH}=2,60 \mathrm{~min}$ of agitation time, $300 \mathrm{rpm}$, PSSP dosage: $0.4 \mathrm{~g} / 500 \mathrm{~mL}$ and initial concentration of chromium (VI): $20 \mathrm{mg} / \mathrm{L}$. Substantial adsorption capacity of $22.5 \mathrm{mg} / \mathrm{g}$ is observed towards chromium(VI). The interference caused by the presence of five-fold excess of co-ions which are naturally present in water caused marginal interference. The spent PSSP can be regenerated with $0.1 \mathrm{M} \mathrm{NaOH}$ and reused until three cycles.

\section{ACKNOWLEDGEMENTS}

The authors thank authorities of K L University, Vaddeswaram, India for providing the necessary research facilities and financial help to carry out this work.

\section{CONFLICT OF INTEREST}

The authors declare that there is no conflict of interests regarding the publication of this article.

\section{REFERENCES}

1. Z. Kowalski, J. Hazard. Mater, 37, 137 (1994); https://doi.org/10.1016/0304-3894(94)85042-9.

2. R. Mehra and M. Juneja, Indian J. Biochem. Biophys., 40, 131 (2003).

3. J. Kotas and Z. Stasicka, Environ. Pollut., 107, 263 (2000); https://doi.org/10.1016/S0269-7491(99)00168-2.

4. S.P.B. Kamaludeen, K.R. Arunkumar, S. Avudainayagam and K. Ramasamy, Indian J. Exp. Biol., 41, 972 (2003).

5. A. Vengosh, R. Coyte, J. Karr, J.S. Harkness, A.J. Kondash, L.S. Ruhl, R.B. Merola and G.S. Dywer, Environ. Sci. Technol. Lett., 3, 409 (2016); https://doi.org/10.1021/acs.estlett.6b00342.

6. A.R. Kumar and P. Riyazuddin, Environ. Monit. Assess., 176, 647 (2011); https://doi.org/10.1007/s10661-010-1610-5.

7. M.F. Gatti, T. Gagliardi, F. Cuccaro, L. De Maria, A. Caputi, M. Quarato and A. Baldassarre, Environ. Sci. Pollut. Res. Int., 24, 11528 (2017). https://doi.org/10.1007/s11356-017-8827-6.

8. H. Oliveira, J. Botany, 2012, Article ID 375843 (2012); https://doi.org/10.1155/2012/375843.

9. R.K. Trivedy, Pollution Management in Industries, Environmental Publications (1989).

10. S.A. Cavaco, S. Fernandes, M.M. Quina and L. Ferreira, J. Hazard. Mater, 144, 634 (2007); https://doi.org/10.1016/j.jhazmat.2007.01.087.

11. S. Parlayici, V. Eskizeybek, A. Avci and E. Pehlivan, J. Nanostruct. Chem., 5, 255 (2015); https://doi.org/10.1007/s40097-015-0156-z.

12. B. Kakavandi, R.R. Kalantary, M. Farzadkia, A.H. Mahvi, A. Esrafili, A. Azari, A.R. Yari and A.B. Javid, J. Environ. Health Sci. Eng., 12, 115 (2014); https://doi.org/10.1186/s40201-014-0115-5. 
13. D. Mohan, K.P. Singh and V.K. Singh, Ind. Eng. Chem. Res., 44, 1027 (2005); https://doi.org/10.1021/ie0400898.

14. M. Vasanthy, M. Sangeetha and R. Kalaiselvi, J. Ind. Pollut. Control, 20, 37 (2004).

15. S. Dahbi, M. Azzi, N. Saib and M. De la Guardia, Anal. Bioanal. Chem., 374, 540 (2002); https://doi.org/10.1007/s00216-002-1490-9.

16. A.J. Thatheyus and D. Ramya, Sci. Int., 4, 74 (2016); https://doi.org/10.3923/sciintl.2016.74.79.

17. C. Covarrubias, R. Arriagada, J. Yáñez, R. García, M. Angélica, S.D. Barros, P. Arroyo and E.F. Sousa-Aguiar, J. Chem. Technol. Biotechnol., 80, 899 (2005); https://doi.org/10.1002/jctb.1259.

18. M.A. Binabaj, S.M. Nowee and N. Ramezanian, Int. J. Environ. Sci. Technol., 15, 1509 ( (2018); https://doi.org/10.1007/s13762-017-1476-y.

19. G.N. Manju and T.S. Anirudhan, Indian J. Environ. Health, 39, 289 (1997).

20. B. Preetha and T. Viruthagiri, Biochem. Eng. J., 34, 131 (2007); https://doi.org/10.1016/j.bej.2006.11.022.

21. L.J.Yu, S.S. Shukla, K.L. Dorris, A. Shukla and J.L. Margrave, J. Hazard. Mater, 100, 53 (2003); https://doi.org/10.1016/S0304-3894(03)00008-6.

22. V. Sarin and K.K. Pant, Bioresour. Technol., 97, 15 (2006); https://doi.org/10.1016/j.biortech.2005.02.010.

23. R. Shyamala, S. Sivakamasundari and P. Lalitha, J. Ind. Pollut. Control, 21, 31 (2005).

24. T. Karthikeyan, S. Rajgopal and L.R. Miranda, J. Hazard. Mater, 124, 192 (2005) https://doi.org/10.1016/j.jhazmat.2005.05.003.

25. V. Vinodhini and N. Das, Am.-Eurasian J. Sci. Res., 4, 324 (2009).

26. I. Anastopoulos, M. Karamesouti, A.C. Mitropoulos and G.Z. Kyzas, J. Mol. Liq., 229, 555 (2017); https://doi.org/10.1016/j.molliq.2016.12.096.

27. O.S. Devi and K. Ravindhranath, Indian J. Environ. Protect., 32, 943 (2012).

28. A.N. Babu, G.V. Krishna Mohan and K. Ravindhranath, Int. J. Chemtech Res., 9, 506 (2016).

29. Y. Hanumantha Rao and K. Ravindhranath, Der Pharma Chemica, 7, 286 (2015)

30. K.P.C. Sekhar, R.V. Vishnu Babu, D. Srividhya and K. Ravindhranath, Der Pharma Chemica, 4, 664 (2012).

31. Y.H. Rao and K. Ravindhranath, Rasayan J. Chem., 10, 1104 (2017); https://doi.org/10.7324/RJC.2017.1041829.
32. R.H. Krishna Reddy, N.N. Malleswara Rao, J.V. Suman Krishna and K. Ravindhranath, Der Pharma Chemica, 8, 47 (2016).

33. V.K. Veni and K. Ravindhranath, J. Chem. Pharm. Res., 4, 656 (2012).

34. S. Ravulapalli and K. Ravindhranath, J. Fluorine Chem., 193, 58 (2017); https://doi.org/10.1016/j.jfluchem.2016.11.013.

35. A.Naga Babu, G.V. Krishna Mohan, K. Kalpana and K. Ravindhranath J. Environ. Chem. Eng., 6, 906 (2018); https://doi.org/10.1016/j.jece.2018.01.014.

36. M. Suneetha, B.S. Sundar and K. Ravindhranath, Int. J. Environ. Technol. Manag., 18, 420 (2015); https://doi.org/10.1504/IJETM.2015.073079.

37. M. Suneetha and K. Ravindhranath, Asian J. Water Environ. Pollut., 14, 71 (2017); https://doi.org/10.3233/AJW-170017.

38. R. Sujitha and K. Ravindhranath, J. Anal. Methods Chem., 2017, Article ID 3610878 (2017); https://doi.org/10.1155/2017/3610878.

39. G.V. Krishna Mohan, A.N. Babu, K. Kalpana and K. Ravindhranath, Asian J. Chem., 29, 2549 (2017); https://doi.org/10.14233/ajchem.2017.20864.

40. Naga Babu, G.V. Krishna Mohan, K. Kalpana and K. Ravindhranath, J. Anal. Methods Chem., 2017, Article ID 4650594 (2017). https://doi.org/10.1155/2017/4650594.

41. A.I. Vogel, A Text Book of Quantitative Inorganic Analysis including Elementary Instrumental Analysis, ELBS. edn 3 p. 792 (1961).

42. K. Selvi, S. Pattabhi and K. Kadirvelu, Bioresour. Technol., 80, 87 (2001); https://doi.org/10.1016/S0960-8524(01)00068-2.

43. G. Alaerts, V. Jitjaturunt and P. Kelderman, Water Sci. Technol., 21, 1701 (1989); https://doi.org/10.2166/wst.1989.0148.

44. Y.-W. Cui, J. Li, Z.-F. Du and Y.-Z. Peng, PLoS One, 11, e0161780 (2016); https://doi.org/10.1371/journal.pone.0161780.

45. D. Sharma and C. Forster, Bioresour. Technol., 47, 257 (1994); https://doi.org/10.1016/0960-8524(94)90189-9.

46. V. Garg, R. Gupta, R. Kumar and R. Gupta, Bioresour. Technol., 92, 79 (2004); https://doi.org/10.1016/j.biortech.2003.07.004.

47. G. Cimino, A. Passerini and G. Toscano, Water Res., 34, 2955 (2000); https://doi.org/10.1016/S0043-1354(00)00048-8.

48. F. Acar and E. Malkoc, Bioresour. Technol., 94, 13 (2004); https://doi.org/10.1016/j.biortech.2003.10.032. 